\title{
KOLABORASI KREATIF KEGIATAN PARIWISATA DAN PELESTARIAN BUDAYA DI TAMAN BUDAYA YOGYAKARTA (TBY)
}

\author{
Yulita Kusuma Sari ${ }^{(1)}$, Agita Santa Maria ${ }^{(2)}$, Riris Rinonce Hapsari ${ }^{(3)}$ \\ (1)(2)(3) Program Studi Pariwisata, Universitas Gadjah Mada \\ yulita.kusumasari@ugm.ac.id, agitasm306@gmail.com,rinoncehapsari@gmail.com
}

Submitted : 11 March 2020 Revised:13 April 2020

Accepted :16 April 2020

\begin{abstract}
Sebagai kota budaya, kota seni, kota pendidikan, dan kota pariwisata, Yogyakarta berpotensi untuk berkembang sebagai kota kreatif. Saat ini, konsep kota kreatif banyak digunakan sebagai konsep perencanaan untuk menyelesaiakan isu sosial budaya dan ekonomi di perkotaan untuk mendukung pembangunan berkelanjutan. Aktifitas interaksi di dalam maupun antar komunitas merupakan nyawa yang menjadi motor penggerak kehidupan bagi kota kreatif. Berbagai studi menunjukkan bahwa ruang interaksi berperan penting dalam terlaksananya kegiatan kreatif pada wisata perkotaan, interaksi dapat menghasilkan gagasan atau metode baru dari yang terdahulu ada. Taman Budaya Yogyakarta (TBY) merupakan salah satu fasilitas ruang interaksi publik milik pemerintah di Kota Yogyakarta yang banyak digunakan untuk penyelenggaraan acara seni dan budaya. Penelitian ini bertujuan untuk memahami pola kolaborasi kreatif dari kegiatan pariwisata dan pelestarian budaya di TBY. Dengan menggunakan metode induktif dan data kualitatif yang didapatkan dari observasi lapangan, dan wawancara, setiap aspek aktivitas di TBY akan dianalisis mengenai bentukbentuk kolaborasi kreatif, aktor, dan pola kolaborasi kreatif. Hasil menunjukkan bahwa kolaborasi kreatif muncul dari aspek nilai-nilai kegiatan, bentuk kegiatan, manajemen kegiatan, serta peranan pemangku kepentingan. Terwujudnya kolaborasi kreatif didukung oleh komunitas sebagai aktor penggerak dominan penyelenggaraan acara di TBY. Peran TBY sebagai daya tarik wisata sekaligus sarana pelestarian budaya juga disadari oleh pemerintah dan pengelola yang kemudian mengatur pergerakan kegiatan melalui kebijakan dan peraturan. Selain itu, motivasi dan persepsi masyarakat terhadap pariwisata budaya yang berkembang seiring pesatnya informasi juga mempengaruhi terwujudnya kolaborasi kreatif pariwisata dan pelestarian budaya di TBY.
\end{abstract}

Kata Kunci: Kolaborasi Kreatif, Konservasi Budaya, Taman Budaya Yogyakarta

\section{CREATIVE COLLABORATION OF TOURISM ACTIVITIES AND CULTURE PRESERVATION IN TAMAN BUDAYA YOGYAKARTA (TBY)}

\begin{abstract}
Yogyakarta has potential capacity in developing it to be a creative city due to its being cultural, art, education, and tourism city. Today, the concept of creative city is often used in planning concepts to offer a way in solving social, cultural, and economic problems in a city whenever it concerns sustainable development and the most important factor in this issue is human beings who inhabit the city. Human beings, the people as a local community, are the
\end{abstract}


soul that enables the creative city to be alive. Many studies show that interaction space plays an important role in a creative city as it is with this interaction that creative activities take place, and this is significant in developing city tourism. It is with this interaction that new ideas or new methods may appear. It is in this context that this research is conducted. It focuses on how a group of people create a collaborative work in cultural preservation and tourism. This interaction space is called Taman Budaya Yogyakarta (TBY). TBY, or Yogyakarta Culture Space, provides a space for communities to hold art and cultural events. With the objective of mapping the creative collaboration facilitated by TBY in the effort to preserve the culture, this research finds out the creative patterns in each aspect of cultural activities which bears cultural preservation and tourism aspects. The creativity patters appear in activity values, form, management and the role of the stakeholders. The creative collaboration is supported by dominant actors in providing the activities in TBY. TBY is therefore a driving factor in not only cultural preservation but also in tourism. Government role and people's perception and motivation developing along with the development of information technology also contributes to the success of tourism creative collaboration and cultural preservation in TBY.

Keywords: Creative Collaboration, Culture Preservation, Taman Budaya Yogyakarta

\section{PENDAHULUAN}

Konsep kota kreatif banyak digunakan sebagai konsep perencanaan kota yang potensial untuk menyelesaiakan isu permasalahan-permasalahan sosial budaya dan ekonomi di perkotaan (Kakiuchi, 2016). Keadaan ini merupakan pengembangan dari konsep sebelumnya yang lebih mengutamakan aspek budaya (tangible dan intangible).

UNESCO Creative City Network (UCCN) dibentuk pada tahun 2004 sebagai bentuk keseriusan mendukung konsep kota kreatif untuk mencapai Sustainable Development Goals/SDGs (sebelumnya dikenal dengan Millennium Development Goals/MDGs). Laporan tahunan UNDP/UNESCO yang bertajuk Creative Economy Report 2013 menyebutkan bahwa dari beberapa studi kasus, kreativitas dan budaya merupakan penentu arah bagi pembangunan berkelanjutan serta merupakan hal mendasar untuk meraih pembangunan berkelanjutan yang inklusif dan adil (Rosi, 2014).

Menurut Rodrigues (2020), kreativitas dianggap sebagai pendorong inovasi dan kewirausahaan perkotaan, yaitu dengan cara merangsang kolaborasi dalam proses pembentukan jejaring antar pemangku kepentingan. Kreativitas dan kolaborasi merupakan pendorong penting dari pertumbuhan kota yang cerdas (smart city) dan berkelanjutan untuk era pengetahuan, teknologi, dan peran budaya, serta inklusi sosial dan lingkungan. Lebih lanjut disebutkan bahwa proses kreatif dan kolaborasi harus fokus pada tujuan revitalisasi ekonomi perkotaan, dengan cara mengidentifikasi sumber daya dan kompetensi yang dimiliki kota masingmasing. Selanjutnya, kolaborasi antar disiplin bidang sangat penting untuk mewujudkan inovasi, serta menimbulkan dampak besar pada kreativitas (Baer, 2015; Dino, 2015; Ness \& Søreide, 2014 dalam Moirano, 2019). Dua hal yang kemudian digaris bawahi dari pernyataan tersebut yaitu: 1). Kreativitas dan kolaborasi harus sesuai dengan sumber daya kota, 2). Kolaborasi dilakukan antar disiplin bidang.

Yogyakarta, sebagai Daerah Istimewa menyadari kekuatan dan peluangnya untuk mewujudkan kreativitas dan kolaborasi. Yogyakarta memiliki potensi seni dan budaya cukup besar, selain itu juga dikenal sebagai 
kota pendidikan, dan kota pariwisata. Yogyakarta disebut sebagai Daerah Istimewa karena bentuk pemerintahan kerajaan masih melekat kuat dan bersinergi dengan posisi administrasi Yogyakarta sebagai provinsi di bawah Negara Indonesia. Kerajaan (Mataram) yang saat ini dipimpin Sri Sultan Hamengkubuwono $\mathrm{X}$ sebagai raja sekaligus gubernur, Yogyakarta hidup dengan warisan seni dan budaya yang masih terus bertahan hingga saat ini. Seni selalu ada di setiap sudut kota, banyak pendatang untuk belajar seni dan budaya, budayawan aktif berkesenian dan melakukan kajian budaya melalui berbagai media langsung dan tidak langsung.

Selain budaya yang tidak tampak (intangible), seni dan warisan budaya tampak (tangible) menjadi daya tarik wisatawan berkunjung ke Yogyakarta yang juga terkenal sebagai Kota Pariwisata. Sebagai bukti, dalam Laporan Tahunan Pariwisata Daerah Istimewa Yogyakarta (DIY) tahun 2016, disebutkan Bahwa jumlah kunjungan wisatawan ke DIY terus naik dari tahun ke tahun (lihat Tabel 1). Dari jumlah kunjungan tersebut,paling banyak kunjungan adalah ke Kota Yogyakarta untuk mengunjungi daya tarik wisata budaya seperti Kraton Yogyakarta, Pagelaran Wayang Kraton, Makam Raja-Raja, Tamansari, Museum, Taman Pintar, dan Gedung Agungi.

Tabel. 1. Data Pertumbuhan Kunjungan Wisatawan Domestik dan Mancanegara ke DIY tahun 2014-2018

\begin{tabular}{lllll}
\hline Tahun & Wisman & $\begin{array}{l}\text { Pertum- } \\
\text { buhan } \\
(\%)\end{array}$ & & $\begin{array}{l}\text { Pertum- } \\
\text { buhan } \\
\mathbf{( \% )}\end{array}$ \\
\hline 2014 & 254.213 & 16,62 & 3.091 .967 & 50,36 \\
\hline 2015 & 308.485 & 21,35 & 3.813 .720 & 23,34 \\
\hline 2016 & 355.313 & 15,18 & 4.194 .261 & 9,98 \\
\hline 2017 & 397.951 & 12,00 & 4.831 .347 & 15,19 \\
\hline 2018 & 416.372 & 4,63 & 5.272 .719 & 9,14 \\
\hline
\end{tabular}

Sumber: Laporan Statistik Kepariwisataan DIY tahun 2018

$\begin{array}{lcr}\text { Perkembangan } & \text { teknologi } & \text { informasi } \\ \text { menyebabkan } & \text { pariwisata } & \text { berkembang }\end{array}$

menjadi industri yang bergerak semakin cepat. Sementara itu, dalam berbagai tulisan, dipercaya bahwa pariwisata juga dapat memberikan imbas negatif berupa degradasi terhadap budaya. Degradasi budaya akibat adanya pariwisata diantaranya dapat berupa adanya komodifikasi budaya, dan hilangnya nilai budaya, Tantangan pada era globalisasi ini adalah bagaimana kegiatan pariwisata dan pelestarian budaya dapat berkolaborasi bersama untuk mencapai tujuan masingmasing.

Menurut MacLeod (2004) dan Ritzer (2011), globalisasi menyebabkan terjadinya perubahan-perubahan budaya dalam kehidupan bermasyarakat. Tiga hal yang mencirikan globalisasi yaitu pertama, terjadinya homogenitas, kecenderungan trend yang sama, tujuan-tujuan serupa terjadi di kelompok-kelompok yang berbeda. Yang kedua, sebagai kebalikannya muncul heterogenitas khususnya pada kelompok kelompok masyarakat yang memiliki kecenderungan konsep yang sama. Ketiga, hibriditas, yaitu konsep baru yang terbentuk dari perubahan-perubahan dan/ atau pembauran dua konsep terdahulu, hibriditas dalam bidang budaya mungkin terjadi arena sifat dinamisnya. Kedinamisan terjadi karena adanya interaksi dengan budaya lain yang tidak dapat dielakkan.

Dalam pariwisata, globalisasi menyebabkan perjalanan menjadi lebih mudah, the world without border adalah frasa yang paling tepat untuk mengambarkannya. Perjalanan wisata menimbulkan interaksi budaya dari dua atau lebih budaya, yaitu host-guest atau guest-guest.

Sifat dinamis budaya menyebabkan kegiatan pelestarian budaya memiliki tantangan besar. Pelestarian budaya adalah perihal yang sangat kompleks. Pada faktanya, kita tidak dapat mempertahankan satu budaya untuk selalu sama dalam rentang waktu yang berbeda. Paling memungkinkan dari pelestarian budaya yaitu mempertahankan 
nilai-nilai yang dianggap baik oleh satu kelompok masyarakat tertentu. Oleh karena itu, kegiatan pelestarian budaya di Yogyakarta akan menjadi besar tantangannya, karena berjalan beriringan dengan pariwisata. Keduanya bidang tersebut sama-sama kuat.

Bagi sebuah kota kreatif, komunitas lokal merupakan nyawa yang menjadi motor penggerak kehidupan (Sofield, dkk, 2017). Aktivitas kota bergerak oleh ide-ide kreatif komunitas yang masuk ke dalam berbagai lini bidang. Secara spontan, komunitas ini memiiki kemampuan mengundang orang di luar komunitasnya dan membentuk ruangruang interaksi sosial. Fenomena ini juga tampaknya ditangkap oleh bidang ekonomi kreatif, yaitu dengan besarnya permintaan (demand) kebutuhan ruang interaksi sosial, terciptalah penawaran (supply) pada hal tersebut. Café merangkap ruang pameran seni, taman dan jalanan dapat menjadi mimbar dan kelas bagi musisi, penari, pelukis, atau seniman kriya. Daya tarik wisata Yogyakarta ada di setiap sudut kotanya.

Taman Budaya Yogyakarta merupakan salah satu ruang interaksi budaya yang dibangun sejak tahun 1977, TBY menempati Gedung Societet pada tahun 2002.TBY telah lama ada dan dikenal baik oleh seniman, budayawan, masyarakat, dan wisatawan. Hingga saat ini TBY seringkali digunakan oleh komunitas untuk melangsungkan acara dan dapat dikonsumsi publik.

Mengapa TBY? Dalam pencarian acak melalui platform Google tentang TBY, ditemukan bahwa kata-kata yang sering dituliskan dalam Ulasan Google yaitu: 1) Tempat Budaya dan Berkesenian, 2) Tempat Wisata. Pencarian serupa muncul dari situs Wisata Tripadvisorii. Hal ini jelas terlihat bahwa TBY memegang peranan bagi dua kepentingan, pariwisata dan pelestarian budaya. Penting bagi para pemangku kepentingan untuk memahami trend perubahan untuk saling beradaptasi. Maka, adaptasi terhadap pengaruh perubahan memiliki sifat "saling", yaitu adanya ketercapaian tujuan bagi dua kepentingan. Kuatnya dua kepentingan ini juga ditunjukkan pada kegiatan-kegiatan budaya dan pariwisata yang selalu diperbaharui melalui website resmi TBY.

Hal inilah yang mendasari pentingnya untuk menemukenali pola-pola kolaborasi kreatif yang terjadi di TBY. Kolaborasi tersebut mungkin terjadi antar pemangku kepentingan, dalam berbagai bentuk kegiatan, pada beragam tahapannya, dalam setiap nilai-nilai dalam proses kegiatan, atau tidak menutup kemungkinan temuan lain terkait kolaborasi kreatif kegiatan pariwisata dan pelestarian budaya di TBY.

Dari uraian latar belakang tersebut, maka muncul pertanyaan sebagai berikut: 1). Dalam bentuk apa kolaborasi antara pariwisata dan pelestarian budaya yang dilakukan oleh pemangku kepentingan di Taman Budaya Yogyakarta di TBY, 2) siapakah aktor yang berperan dalam kolaborasi kreatif ini?, dan 3) Bagaimana pola kolaborasi kreatif pariwisata dan pelestarian budaya?

Secara umum, tulisan ini diharapkan dapat berkontribusi terhadap dua hal, yaitu: (i) terhadap munculnya pemahaman dan kekritisan berpikir pembaca terhadap bentuk adaptasi kolaborasi kreatif aktivitas pariwisata dan pelestarian budaya di ruang interaksi, dalam kasus ini adalah TBY serta (ii) terhadap peran pemangku kepentingan penggerak pariwisata dan pelestarian budaya demi mewujudkan pembangunan berkelanjutan.

Sedangkan secara praktis penelitian ini dapat digunakan untuk memberi masukan bagi kebijakan pengembangan pariwisata, khususnya wisata perkotaan di Kota Yogyakarta yang mendukung konsep pembangunan yang berkelanjutan. 
Yulita Kusuma Sari; Agita Santa Maria; Riris Rinonce Hapsari: Kolaborasi Kreatif Kegiatan Pariwisata dan Pelestarian Budaya di Taman Budaya Yogyakarta (TBY)

\section{TINJAUAN PUSTAKA}

Tulisan mengenai aktivitas pariwisata dan pelestarian budaya khususnya yang berhubungan dengan kegiatan kreatif salah satunya yang ditulis oleh Sangchungnom (2018) tentang hubungan antara komunitas kreatif (creative community) dan perkembangan kegiatan pariwisata di Thailand. Dalam tulisannya disebutkan bahwa komunitas kreatif dengan potensi budaya lokal memegang peranan penting dalam pengembangan atraksi pariwisata di Thailand.

Sofield, dkk (2017), mengkomparasikan ruang-ruang interaksi yang dibentuk oleh komunitas (communities place-making) di Kota Tasmania, kemudian hasilnya menunjukkan bahwa aktivitas yang diselenggarakan oleh komunitas-komunitas di tersebut muncul nilai-nilai pelestarian tradisi dan budaya setempat, luaran dari acara tersebut juga mendukung kegiatan pariwisata di kota tersebut.

Selanjutnya Vivant (2013) dalam artikelnya menyatakan tentang dukungan kebijakan pemerintah dalam aspek pengembangan manusia dalam kerangka pengembangan kota kreatif (creative city), menurutnya manusia merupakan aset penting dalam pengembangan kota kreatif dan pemerintah dapat mengambil peran sebagai fasilitator serta pengendali arah pengembangan melalui kebijakan.

Beberapa artikel dan tulisan yang mengenai TBY ditemukan, tulisan tersebut secara spesifik membahas mengenai kesenian atau pertunjukan. Meskipun dalam kenyataanya TBY saat ini bertransformasi dari tujuan awalnya, hingga saat ini belum ditemukan riset atau artikel mengenai pariwisata di TBY.

\section{Kolaborasi antara Pelestarian Budaya- Pariwisata}

Kolaborasi dalam kamus besar Bahasa Indonesia (KBBI) ditulis sebagai: kolaborasi/ko la labo ra·si/memiliki arti $n$ (perbuatan) kerja sama (dng musuh dsb). Sedangkan apabila kita menilik pada Kamus Bahasa Inggris (Oxford Dictionary atau Merriam-Webster Dictionary), kolaborasi mengandung arti: (1) the act of working with another person or group of people to create or produce something (uncountable), atau (2) a piece of work produced by two or more people or groups of people working together (countable), Dari situ dapat dilihat bahwa kolaborasi dapat berupa sebuah aksi/proses, atau kebendaan. Sementara itu, masih dalam Kamus Bahasa Indonesia (KBBI), kreatif berarti kre.a.tif/ /kréatif/ 1) memiliki daya cipta; memiliki kemampuan untuk menciptakan; 2) bersifat (mengandung) daya cipta.

Menurut Inskeep (1991), pemangku kepentingan yang terlibat dalam pariwisata memegang peranan penting dalam mewujudkan pariwisata yang berkelanjutan (Tourism Sustainability). Dalam hal ini, pemangku kepentingan yang terlibat secara langsung antara lain wisatawan, masyarakat lokal, dan pengelola. Sementara yang tidak terlibat secara langsung antara lain pemerintah dan akademisi atau lembaga non profit. Masyarakat dan pengelola merupakan kunci dalam industri pariwisata yang memerankan dua hal besar. Satu, mereka berperan sebagai penghubung antara wisatawan dan daya tarik wisata. Kedua mereka berperan sebagai daya tarik wisata itu sendiri.

Tingkat kompleksitas pembangunan pariwisata yang berkelanjutan di kawasan perkotaan berhubungan dengan keterbatasan sumber daya alam, dan segmen wisata khusus, sehingga wisata perkotaan lebih banyak menggunakan sumber daya hasil budaya manusia. Menurut Bock (2015), saat ini wisata perkotaan dianggap sebagai sektor vital dalam meningkatkan pendapatan dan tingkat keterserapan tenaga kerja. Lebih lanjut, terdapat 5 pendekatan untuk meneliti 
wisata perkotaan yaitu: pendekatan ekologi, pendekatan sosio-kultur (manusia), pendekatan fisik, pendekatan kebijakan, dan pendekatan gabungan (mixed of both approaches).

Dalam pendekatan sosio-kultur disebutkan bahwa objek utama dalam pembangunan wisata perkotaan adalah aktivitas masyarakat. Mengidentifikasi masyarakat sebagai subjek penggerak pariwisata di perkotaan akan berbeda dengan destinasi wisata lain. Kondisi demografi masyarakat di perkotaan sangat beragam, sehingga sulit menentukan apakah masyarakat diartikan penduduk asli, atau penduduk yang tercatat secara administratif, atau pendatang juga diikutsertakan. Maka, kebanyakan penelitian mengenai pariwisata perkotaan akan mengartikan masyarakat sebagai komunitas-komunitas terlibat. Lebih lanjut, komunitas memiliki kekuatan untuk mengkreasi bentuk-bentuk baru. Meskipun begitu ada pihak lain yang kemudian mendukung pergerakan komunitas ini. Oleh karena itu penting untuk melihat keterlibatan stakeholders kedalam bentuk-bentuk adaptasi perubahan-perubahan budaya karena kegiatan wisata. Dalam artikel lain, Vivant (2013) meyatakan bahwa terkadang kebijakan pemerintah tidak mendukung dan kurang sejalan dengan visi misi kota kreatif. Padahal kebijakan ini merupaka kunci keberhasilan pembangunan kota kreatif. Pembuktian akan generalisasi ini perlu menggunakan penelitian lapangan khususnya pada studi kasus TBY.

Mengenai pelestarian budaya lokal, artinya mempertahankan nilai-nilai seni budaya, nilai tradisional dengan mengembangkan perwujudan yang bersifat dinamis, menyesuaikan dengan situasi dan kondisi yang selalu berubah dan berkembang. Salah satu tujuan diadakannya pelestarian budaya adalah juga untuk melakukan revitalisasi budaya (penguatan). Alwasilah (2006) mengatakan adanya tiga langkah dalam pelestarian budaya, yaitu: (1) pemahaman untuk menimbulkan kesadaran, (2) perencanaan secara kolektif, dan (3) pembangkitan kreatifitas kebudayaaan (lihat Gambar 1).

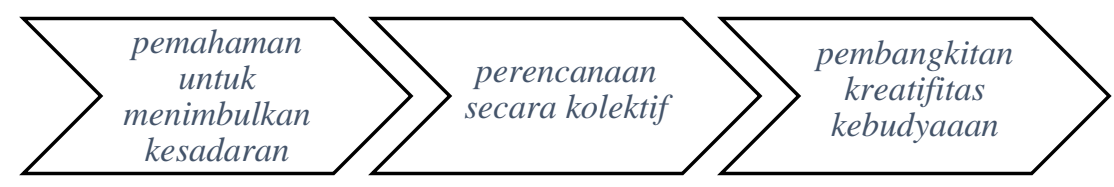

\section{Gambar 1. Prinsip dalam revitalisasi sebagai bentuk pelestarian budaya}

Sumber. Alwasilah, 2006

Lebih lanjut dikatakan bahwa pada dasarnya, proses melestarikan kebudayaan itu adalah pada hakekatnya akan mengarah kepada perilaku kebudayaan dengan sendirinya, jika dilakukan secara terus menerus dan dalam kurun waktu tertentu. Kelestarian tidak mungkin berdiri sendiri, oleh karena senantiasa berpasangan dengan perkembangan, dalam hal ini kelangsungan hidup.

Selanjutnya Mill dan Morison (1985) menyatakan bahwa Pariwisata adalah sebuah sistem. Artinya, pariwisata terdiri dari bagian-bagian yang saling berkaitan dan mempengaruhi satu sama lain. Empat komponen dalam sistem pariwisata:

1) Wisatawan, yaitu segala macam permintaan dan motivasi dari seseorang yang hendak atau telah melakukan perjalanan.

2) Perjalanan, yaitu segala yang berhubungan dengan kegiatan perjalanan menuju tujuan wisata 
Yulita Kusuma Sari; Agita Santa Maria; Riris Rinonce Hapsari: Kolaborasi Kreatif Kegiatan Pariwisata dan Pelestarian Budaya di Taman Budaya Yogyakarta (TBY)

3) Destinasi, didalamnya mencakup komponen atraksi wisata, fasilitas \& amenitas, aksesibilitas, dan manajemen destinasi

4) Pemasaran,mencakup segala aspek penyampaian informasi destinasi ke target, yaitu wisatawan atau calon wisatawan. Wisatawan tidak dapat dikatakan melakukan kegiatan berwisata apabila tidak melakukan perjalanan, tidak mengunjungi destinasi, dan tidak merasakan pengalaman dari kunjungan tersebut. Keputusan wisatawan dalam memilih destinasi tujuan dipengaruhi oleh pemasaran destinasi tersebut. Didalamnya terdapat produk wisata, tempat dan saluran distribusi wisata, promosi, dan pertimbangan harga.

\section{METODE}

Penelitian ini merupakan penelitian induktif dengan data kualitatif. Data primer didapatkan dengan 3 (tiga) cara antara lain: (i) Observasi Lapangan pada kegiatankegiatan yang berlangsung di TBY, (ii) Studi Literatur terhadap laporan-laporan kegiatan dan penelitian terdahulu, peraturan terkait, artikel jurnal, dan buku-buku terkait, (iii) Wawancara mendalam terhadap narasumber terpilih, antara lain dari komponen pengelola, wisatawan TBY, dan pelaksana kegiatan di TBY. Data diolah dengan mengelompokkan sesuai dengan variabel yang telah disebutkan dalam landasan teori. Reduksi data digunakan sebagai metode untuk penyesuaian terhadap topik penelitian.

\section{HASIL DAN PEMBAHASAN}

Sebagai pusat budaya termasuk di dalamnya pengembangan dan pengolahan pusat dokumentasi, etalase, dan informasi seni budaya dan pariwisata, TBY pada mula nya berdiri 11 Maret 1977 dengan nama Purna Budaya berlokasi di kompleks Universitas Gadjah Mada. Pada tahun 2002, aktivitas TBY dipindah ke kawasan Benteng
Vredeburg, dekat dengan kawasan Malioboro dan pusat kota, menempati bekas gedung Societet Militair, salah satu peninggalan masa pendudukan colonial Belanda. Terdapat dua bagian utama di area gedung TBY. Yang pertama Gedung Concert Hall berfungsi sebagai tempat diskusi sastra, penyelenggaraan pameran, dan pelatihan. Kedua, Gedung utama Societet Militair berfungsi sebagai pentas teater, tari, musik, dan berbagai pertunjukan seni lainnya. Kompleks Gedung Societet Militair memiliki fasilitas ruang pertunjukan dengan kapasitas 500 penonton, panggung pertunjukan, peralatan tata cahaya, dan sarana publikasi, perpustakaan, mushola, toilet, kafe, dan tempat parkir.

\section{Pengelolaan Taman Budaya Yogyakarta}

Wewenang pengelolaan TBY ada dibawah pemerintah provinsi Daerah Istimewa Yogyakarta (DIY) tepatnya dibawah Dinas Kebudayaan Probinsi DIY (secara resmi disebut Unit Pelaksana Teknis Dinas). Terdapat tiga bagian dalam pengelolaan TBY, yaitu Sub Bagian Tata Usaha, Seksi Penyajian dan Pengembangan Seni Budaya, dan Seksi Dokumentasi dan Informasi Seni Budaya. Visi TBY adalah: Terwujudnya Taman Budaya Yogyakarta sebagai "The Window of Yogyakarta" menuju pusat budaya terkemuka di tingkat nasional dan internasional. Sedangkan Misi TBY terbagi atas 3 (tiga): (i) Memberikan ruang kreatif bagi seniman dan budayawan untuk mempresentasikan karya kreatif dan pemikiran mereka, (ii) Menjadi suatu pusat laboratorium pengembangan dan pengolahan seni, dokumentasi dan informasi seni budaya, dan (iii) Meningkatkan kompetensi dan kemampuan masyarakat dalam mengapresiasi seni budaya ${ }^{\mathrm{iii}}$.

Pelestarian budaya sekaligus Pengelola TBY terdiri atas pegawai negeri sipil (PNS). Selain itu, terdapat pegawai-pegawai TAP 
(tenaga ahli pratama) yang dipekerjakan dengan sistem kontrak tahunan.

Sejauh ini pengelolaan dan pengambilan keputusan mengenai TBY hanya melibatkan unsur-unsur pemerintahan, kecuali dalam perihal sewa gedung dan pengadaan event yang tetap melibatkan unsur komunitas seni, komunitas pariwisata, pelaku industry, dan masyarakat sekitar. Komunitas ini juga berperan sebagai tenaga ahli dan penasihat bagi pengelola TBY. Isu-isu budaya seringkali dilontarkan dalam rapat internal pengelola Bidang Penyajian dan Pengembangan. Pihak pengelola TBY secara khusus hanya mengijinkan berlangsungnya kegiatan yang berhubungan dengan pelestarian seni dan budaya. Target utama penyelenggaraan kegiatan di TBY umumnya adalah masyarakat Daerah Istimewa Yogyakarta, dan komunitas-komunitas seni dan budaya secara khusus. Publikasi dan promosi kegiatan dilaksanakan oleh Seksi Dokumentasi dan Informasi Seni Budaya dan/atau panitia acara yang bersangkutan melalui website, media sosial, baliho, dan banner.

\section{Kegiatan di Taman Budaya Yogyakarta} Pelestarian Budaya saat ini merupakan kegiatan utama di TBY. Sesuai visi dan misi TBY yang lebih kuat mengarah pada aspek kebudayaan. Pariwisata di TBY muncul secara spontan, dari kegiatan-kegiatan yang terlaksana di TBY. Pengelola TBY memiliki wewenang dalam menentukan jenis kegiatan yang diperbolehkan terlaksana di TBY yaitu kegiatan yang sesuai Visi Misi TBY. Keputusan tersebut dibicarakan internal oleh pengelola melalui rapat atau diskusi sejenis. Dalam waktu Juni 2019 hingga Agustus 2019, terdapat 10 acara sebagai sumber rujukan data. Acara tersebut termasuk dalam kategori pameran seni, pertunjukan seni, seminar dan/atau workshop seni, dan pasar tiban $^{i v}$. Penyelenggaraan acara didominasi oleh pihak diluar pengelola TBY, yaitu komunitas seni, personal, atau institusi/lembaga pendidikan. Lebih lanjut pada sampel kegiatan dalam penelitian ini dapat dilihat pada Tabel 2.

\section{Tabel 2. Acara di TBY selama bulan Juni} s/d Agustus 2019

\begin{tabular}{|c|c|c|}
\hline$\overline{\text { No }}$ & Acara & Deskripsi \\
\hline 1 & $\begin{array}{l}\text { Bimbingan } \\
\text { Seni: Art } \\
\text { for } \\
\text { Children }\end{array}$ & $\begin{array}{l}\text { Dilaksanakan rutin setiap Hari } \\
\text { Sabtu minggu ke-2, ke-3, dan ke-- } \\
4 \text { setiap bulannya. Setiap akhir } \\
\text { tahun ditutup dengan pantas seni } \\
\text { Art for Children, melibatkan } \\
\text { anak-anak, remaja, serta } \\
\text { komunitas seni dan pelaku } \\
\text { industri kecil. }\end{array}$ \\
\hline$\overline{2}$ & $\begin{array}{l}\text { Posthumous } \\
\text { Solo } \\
\text { Exhibition } \\
\text { of } \\
\text { Nyoman I } \\
\text { Sukari } \\
\end{array}$ & $\begin{array}{l}\text { Gabungan Talk Show dan } \\
\text { Pameran Tunggal karya seniman I } \\
\text { Nyoman Sukari (1968-2010). } \\
\text { Merefleksi perjalanan seni I } \\
\text { Nyoman Sukari. }\end{array}$ \\
\hline$\overline{3}$ & $\begin{array}{l}\text { Pameran } \\
\text { Seni Rupa: } \\
\text { Me, My } \\
\text { Self, and I } \\
\end{array}$ & $\begin{array}{lrc}\text { Pameran tunggal perupa } & \text { Dr. } \\
\text { Timbul Raharjo, salah } & \text { satu } \\
\text { seniman kriya di Indonesia. } & \end{array}$ \\
\hline 4 & $\begin{array}{l}\text { Pasar } \\
\text { Kangen } \\
\text { Jogja \#12 }\end{array}$ & $\begin{array}{l}\text { Pasar makanan tradisional, } \\
\text { kerajinan lokal, dan panggung } \\
\text { kesenian yang diadakan setahun } \\
\text { sekali, pertama kali diadakan } \\
\text { tahun 2007. }\end{array}$ \\
\hline$\overline{5}$ & $\begin{array}{l}\text { Pameran } \\
\text { Seni DAM } \\
\# 36 \\
\text { Universitas } \\
\text { Negeri } \\
\text { Yogyakarta } \\
\end{array}$ & $\begin{array}{l}\text { Eksibisi seni rupa tahunan Dosen, } \\
\text { Alumni, Mahasiswa (DAM) } \\
\text { Fakultas Seni, Universitas Negeri } \\
\text { Yogyakarta. }\end{array}$ \\
\hline$\overline{6}$ & $\begin{array}{l}\text { Parade } \\
\text { Dagelan } \\
\text { Mataram }\end{array}$ & $\begin{array}{l}\text { Pertunjukan seni lawak rutin } \\
\text { tahunan diselenggarakan oleh } \\
\text { TBY. Setiap pertunjukannya } \\
\text { mengusung tema berbeda-beda } \\
\text { menyesuaikan isu (sosial budaya- } \\
\text { politik-ekonomi-lingkungan) } \\
\text { pada tahun berlangsung. }\end{array}$ \\
\hline 7 & $\begin{array}{l}\text { Temu } \\
\text { Teater } \\
\text { Mahasiswa } \\
\text { Nusatara } \\
\text { (Temu } \\
\text { Teman) }\end{array}$ & $\begin{array}{llr}\text { Merupakan } & \text { forum temu } \\
\text { mahasiswa seni peran dan para } \\
\text { pelaku seni peran yang Masih } \\
\text { berstatus Mahasiswa dari } \\
\text { berbagai Daerah (nasional). }\end{array}$ \\
\hline
\end{tabular}


Yulita Kusuma Sari; Agita Santa Maria; Riris Rinonce Hapsari: Kolaborasi Kreatif Kegiatan Pariwisata dan Pelestarian Budaya di Taman Budaya Yogyakarta (TBY)

\begin{tabular}{|c|c|c|}
\hline No & Acara & Deskripsi \\
\hline$\overline{8}$ & $\begin{array}{l}\text { "Pusaran": } \\
\text { Pertunjukan } \\
\text { komunitas } \\
\text { Teater } \\
\text { Alam } \\
\end{array}$ & $\begin{array}{l}\text { Pertunjukan dari komunitas } \\
\text { Teater Alam, biasanya } \\
\text { mengangkat isu sosial budaya- } \\
\text { politik-ekonomi-lingkungan), } \\
\text { tahun ini bertajuk "Pusaran". }\end{array}$ \\
\hline 9 & $\begin{array}{l}\text { Screening } \\
\text { Film }\end{array}$ & $\begin{array}{l}\text { Acara diskusi film milik salah } \\
\text { satu fakultas di universitas di } \\
\text { Yogyakarta. }\end{array}$ \\
\hline 10 & $\begin{array}{l}\text { Musik } \\
\text { Malam }\end{array}$ & $\begin{array}{l}\text { Digelar di panggung terbuka } \\
\text { kompleks TBY, merupakan } \\
\text { pertunjukan } \\
\text { dikolaborasikan dengan beberapa } \\
\text { performance art, mulai dari puisi, } \\
\text { tari, teater, seni rupa, dan atraksi } \\
\text { dari komunitas seni. }\end{array}$ \\
\hline
\end{tabular}

Sumber. Olah data, 2019

\section{Kunjungan di Taman Budaya Yogyakarta}

Kunjungan di TBY dipengaruhi oleh penyampaian informasi kegiatan kepada publik. Pada era awal pariwisata, wisatawan mendapat informasi melalui paket Wisata dari travel agency, brosur wisata, leaflet. Namun, di masa sekarang, informasi merupakan hal yang mudah didapatkan wisatawan terutama untuk merencanakan perjalanan secara mandiri. Salah satunya adalah informasi dari internet. Saat mencari ke mesin pencari Google secara umum dengan kata kunci Cultural Attractions in Yogyakarta, maka Taman Budaya Yogyakarta akan muncul dalam deretan paling atas. Melalui website resmi Taman Budaya Yogyakarta, tby.jogjaprov.go.id jadwal acara harian di TBY dapat diakses, Hal ini memudahkan pengunjung merencanakan kunjungan ke Taman Budaya Yogyakarta baik untuk ketertarikan budaya maupun wisata. Lokasi dan jalur kendaraan menuju Taman Budaya Yogyakarta dapat diketahui melalui peta digital dan dilalui menggunakan kendaraan pribadi maupun massal (privat and public transport).

Pola kunjungan ke TBY sangat tergantung pada waktu pelaksanaan, dan jenis acara. Inkonsistensi dalam hal ini terjadi dalam hal, yaitu: kegiatan rutin, khususnya rentang rutin tahunan tidak selalu dilaksanakan pada waktu yang sama tiap tahunnya, bagi pengunjung yang berasal dari luar kota tidak selalu mendapati keberadaan acara di TBY setiap harinya, dan kurangnya info mengenai sarana prasarana penunjang di area TBY.

Pengunjung mengetahui info acara yang dapat diakses dari website resmi TBY, berbagai situs wisata (ct.

https://visitingjogja.com, gudeg.net, https://acaraseni.top, hipwee travel, detik travel, dll), sosial media (Instagram, Twitter, Facebook, dll) menjadi keunggulan TBY dalam mempublikasikan dan mempromosikan acara. Sebagian lain pengunjung mendapatkan informasi dari baliho, poster, serta iklan radio dan televisi.

Sebagai contoh, acara yang rutin dilaksanakan setiap tahun di TBY dalam hal ini adalah Pasar Kangen Jogja, memiliki tingkat kunjungan yang tinggi. Kekurangan dalam hal pengelolaan acara Pasar Kangen Jogja adalah tidak adanya catatan atau data pasti jumlah kunjungan setiap harinya. Lack of data ini menjadi kelemahan dalam pengembangan pengadaan acara di TBY ke depannya.

Berdasarkan wawancara lapangan, pengunjung yang banyak ditemui memiliki keterkaitan internal dengan penyelenggara acara, sebagian lain berasal dari komunitas seni atau serupa. Ada indikasi ragam dan pembauran motivasi kunjungan ke TBY, meskipun pada dasarnya merupakan ketertarikan budaya. Motivasi pengunjung dapat dibedakan menjadi dua kategori besar yaitu (i) murni pelestarian budaya, dan (ii) kombinasi dari pariwisata dan pelestarian budaya. Artinya, setiap acara yang dilangsungkan di TBY selalu mengandung unsur pelestarian budaya. Dapat dikatakan, budaya menjadi daya tarik wisata, dan pelestarian budaya dapat dilakukan menggunakan konsep pariwisata. 


\section{Kolaborasi Kreatif Pariwisata dan Pelestarian Budaya}

Pertanyaan paling mendasar dari hasil observasi dan wawancara lapangan terhadap segala yang berkaitan dengan aktivitas di TBY adalah, apakah setiap kegiatan memiliki nilai pelestarian budaya? Ataukah nilai pariwisata? Atau memiliki keduanya?

Memetakan pola kolaborasi antar dua konsep menjadi sebuah tantangan tersendiri. Pembauran 2 konsep akibat dari globalisasi, pariwisata dan pelestarian budaya menyebabkan batasan prinsip masing-masing konsep menjadi sangat tipis. Sulit untuk dapat mengeluarkan argumen pada aktivitas tertentu manakah konsep yang lebih kuat berperan. Pada perjalanan penelitian, kemudian unit-unit informasi yang ditemukan dilapangan kemudian dapat dikelompokkan menjadi 3 (tiga), yaitu: (i) Kolaborasi Bentuk Kegiatan, (ii) Kolaborasi Nilai-Nilai (values), dan (iii) Kolaborasi Aktor Kegiatan (lihat diagram 1).

Diagram 1. Kolaborasi antara konsep pariwisata dan konsep pelestarian budaya

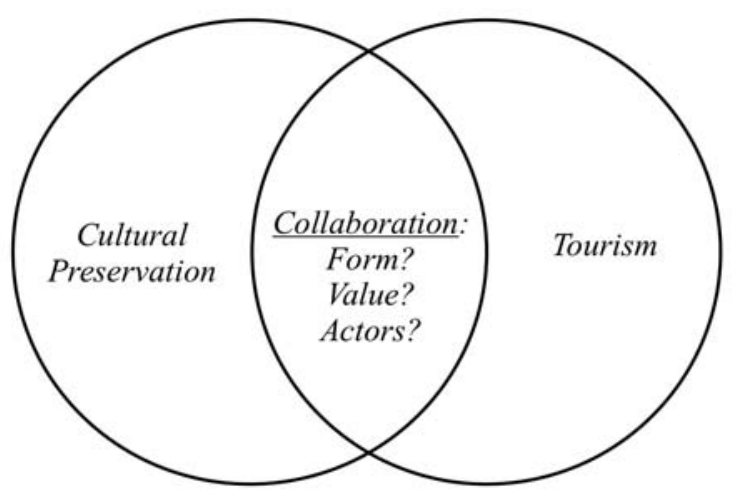

Sumber. Olah data penulis, 2019

\section{Nilai Kreatif (Value)}

Sebagian kegiatan di TBY mengandung salah satu dari nilai pelestarian budaya atau nilai pariwisata. Sebagian diantaranya mengandung kedua nilai. Kegiatan yang mengandung kedua nilai inilah yang dianggap sebagai bentuk kolaborasi kreatif di TBY.

\section{Budaya sebagai objek untuk dilestarikan.}

Peran TBY sebagai media pelestarian budaya sesuai visi misi utama terlihat dari upaya dalam mensupport setiap kegiatan dengan mengatur jadwal dan turut mempublikasikan jadwal tersebut ke website resmi TBY. Sementara penyelenggaraan kegiatan oleh internal pengelola TBY berfokus pada upaya pengembangan TBY, dan upaya transfer ilmu sesama penggiat seni. Kegiatan yang mengandung nilai tersebut antara lain: diskusi dan temu budayawan, serta Bimbingan Seni Art for Children.yang tujuan utama acara tersebut yaitu sebagai media transfer ilmu dan apendalaman pemahaman kebudayaan terhadap generasi muda. Kegiatan yang rutin diselenggarakan (tiga kali setiap bulan) menyesar anak-anak dan remaja sebagai generasi paling krusial dalam menyerap nilainilai budaya melalui kesenian (rupa, vokal, musik, teater, dan tari).

\section{Kolaborasi Kreatif: Budaya sebagai objek (daya tarik) pariwisata}

Upaya kreatif diartikan dengan munculnya kegiatan baru yang bertujuan untuk pelestarian budaya secara dinamis. Pada poin ini, baik pengelola maupun penyelenggara acara melihat kegiatan budaya sebagai produk wisata. Pengelola bahkan sebagian penyelenggara acara di TBY melihat sebuah pagelaran acara bukan hanya sebagai media edukasi dan pelestarian seni budaya, namun berpotensi sebagai produk yang memiliki daya tarik wisata.

Sebagai sebuah produk, artinya pariwisata dilihat sebagai satu kesatuan sistem. Mill and Morisson (1985) pertama kali merumuskan sistem Pariwisata yang terdiri dari komponen wisatawan, Potensi tersebut dapat terlihat dari adanya kanal distribusi yang mempertemukan wisatawan 
dengan daya tarik wisata (Place). Sesuai dengan teori sistem pariwisata, yang membedakan pariwisata dengan industri barang dan jasa lain adalah sifat perjalanan yang mengharuskan wisatawan/pengunjung (pembeli) harus bergerak ke arah daya tarik/atraksi (produk). Aktivitas di TBY dalam hal ini berperan sebagai atraksi wisata, dan TBY adalah destinasi wisata (lihat diagram 2).

Ada banyak yang pemangku kepentingan yang berperan dalam mempertemukan kedua titik ini, peran komunitas, institusi akademis, dan pengelola TBY salah satunya sebagai aktor penggerak dalam terciptanya kolaborasi kreatif. Meskipun sebagian acara bersifat non-profit oriented, namun secara tidak langsung, keberadaan acara-acara di TBY menjadi daya tarik bagi wisatawan dan berpengaruh pada produk dan fasilitas wisata lain, khususnya yang berada di sekitar TBY atau Kota Yogyakarta. Seperti diketahui bahwa jejaring atraksi wisata merupakan salah satu kunci dalam memaksimalkan kegiatan wisata perkotaan dan mendukung pengembangan kota kreatif. Nilai inilah yang disadari oleh pemerintah sebagai bagian strategi pengembangan kota kreatif Yogyakarta.

Prinsip lain dalam kegiatan wisata di TBY yaitu adanya keuntungan secara ekonomi dari atraksi di TBY. Keuntungan secara langsung (direct revenue) didapatkan dari ticket acara dan penyewaan tempat. Selain itu indirect revenue dapat berupa keuntungan para penyewaan tempat, atau keuntungan para peserta pameran Yogyakarta (ct. Pasar Kangen Jogja), serta imbas ekonomi pada area sekitar Taman Budaya Yogyakarta yang berada tepat di area strategis pusat wisata perkotaan. Ciri khas pariwisata salah satunya menimbulkan efek berganda (multiplier effect) secara ekonomi. Pariwisata tidak hanya menimbulkan efek langsung ekonomi namun juga efek tidak langsung pendapatan dari sektor pariwisata.
Adanya kegiatan publikasi kegiatan seni dan budaya sesuai dengan konsep pariwisata sebagai industri. Pangsa pasar nya tentu saja wisatawan yang tertarik dengan seni dan budaya yang menjadi target pariwisata. Hanya saja, tampaknya tidak semua publikasi ditujukan untuk pariwisata. Sebagian penyelenggara acara, khususnya pada kegiatan yang tidak berbayar melakukan publikasi hanya bertujuan diseminasi pengetahuan seni dan budaya. Target pengunjung yang ditetapkan oleh penyelenggara tidak secara langsung dimaknai pariwisata oleh mereka.

Belum muncul indikasi bahwa adanya upaya terhadap perencanaan terhadap kegiatan secara berkesinambungan di TBY baik dari segi pengembangan kegiatan maupun pengembangan fisik. Perbandingan antara kegiatan yang dilaksanakan oleh pihak pengelola internal TBY dengan kegiatan oleh komunitas/organisasi luar belum seimbang. Artinya, pengelola TBY masih bersikap pasif terhadap konsistensi penyelenggaraan acara di TBY.

Beberapa acara yang diselenggarakan pihak luar melibatkan pengelola secara pasif dalam hal: publikasi melalui website resmi TBY, sosial media, dan poster/baliho. Keterlibatan aktif diperlukan untuk pengelola internal agar mereka memahami rangkaian acara keseluruhan, serta sebagai dasar pemahamanan untuk kebijakan pengembangan TBY selanjutnya.

\section{Bentuk Kegiatan Murni untuk Pelestarian Budaya}

Kegiatan pelestarian budaya di TBY memenuhi prinsip pelestarian budaya dengan adanya tujuan edukasi budaya dan menempatkan TBY sebagai wadah pemahaman budaya yang lebih dalam khususnya bagi generasi muda (anak-anak dan remaja). Pertama, kegiatan yang memiliki prinsip kelas. Memiliki prinsip edukasi budaya, mengajarkan ilmu dan nilai- 
nilai budaya melalui kesenian dari para seniman dan budayawan berupa: Seni tari, seni rupa yang terdiri dari lukis dan kriya, seni musik, seni suara, film, dan seni panggung. Kegiatan ini mengharapkan para penerima ilmu dapat memahami, mengembangkan, dan berkreasi untuk seni dan budaya. Di TBY acara yang rutin dilaksanakan saat ini adalah Bimbingan Seni: Art for Children, dengan tema seni yang beragam di setiap pertemuannya, hari minggu pertama, kedua, dan ketiga setiap bulannya. Kegiatan ini telah menampung kurang lebih 400 anak-anak dan remaja.

Kedua, kegiatan yang berbentuk forum dengan tujuan diskusi seni dan budaya. forum ini bersifat internal, tempat para pengambil kebijakan/wewenang, seniman, budayawan, dan para pemerhati seni budaya berkumpul membahas isu-isu mengenai pelestarian budaya, dan peluang-tantangan pengelolaan TBY. Forum yang diselenggarakan oleh pengelola TBY ini merupakan forum tertutup, bukan merupakan kegiatan yang bisa dikunjungi. Forum ini rutin diadakan setiap bulannya, hanya saja tidak selalu sama tanggal atau harinya. Bentuk lain dari forum diskusi ini selama penelitian berlangsung adalah forum yang diselenggarakan oleh institusi akademis dengan cara menyewa tempat. TBY dalam hal ini berperan sebagai venue acara. Acara yang diselenggarakan institusi pendidikan seperti Screening Film juga mengandung unsur edukasi yang tinggi karena target nya spesifik menyasar mahasiswa internal universitas yang bersangkutan dan peminat seni film.

\section{Bentuk Kegiatan Kolaborasi Kreatif Pariwisata dan Pelestarian Budaya \\ a. Pameran/Eksibisi dan Seni Pertunjukan sebagai atraksi wisata.}

Pameran adalah salah satu kegiatan yang paling sering berlangsung di TBY. Jenis pameran adalah pameran seni rupa, musik, tari, dan/atau teatrikal. Pameran berlangsung dalam kurun waktu tertentu dan lebih dari satu hari. Lama waktu setiap pameran berbeda sesuai dengan tujuan, dan kontrak tiap acara dengan pihak pengelola TBY. Seni pertunjukan diselenggarakan sebagai peringatan atas momen tertentu, atau apresiasi pada seniman tertentu, namun juga tak jarang berupa pertunjukan rutin tahunan seperti Parade Dagelan Mataram, Pameran Seni DAM, dan Musik Malam. Tiket masuk diperlukan bagi sebagian acara seni pertunjukan, sementara sebagian merupakan pertunjukan gratis. Pameran dan pertunjukan dalam hal ini berperan sebagai media pelestarian budaya sekaligus atraksi wisata unggulan. Sebagai contoh, Pekan Seni Art For Children merupakan pameran rutin tahunan sebagai luaran hasil kegiatan Bimbingan Seni Art for Children memadukan berbagai pameran seni rupa, dan seni pertunjukan. Acara ini berlangsung selama 4 hari, diikuti Oleh 485 anak dan remaja, dan melibatkan lebih dari 50 komunitas seni budaya, serta jejaring industri pariwisata.

Parade Dagelan Mataram juga merupakan pertunjukan teatrikal untuk diseminasi gagasan dan kritik budaya pada masyarakat.

Sebagian besar pameran dan pertunjukan diselenggarakan secara individu oleh seniman atau komunitas. Dalam hal tersebut, pengelola berhak untuk mengawasi, dan mengendalikan terlaksananya pameran apabila penyelenggaraan acara menyimpang dari ketentuan yang telah ditetapkan pihak pengelola. Penyelenggara menjadi actor utama dalam merencanakan, mendanai, melaksanakan, mempublikasikan, dan mengevaluasi acara mereka masing-masing. Oleh karena itu, motivasi penyelenggara tinggi dalam mensukseskan acara, yang salah satu indikatornya adalah jumlah pengunjung. Sepanjang observasi penelitian, ditemukan bahwa dalam pameran dan pertunjukan ada keterlibatan generasi muda dalam struktur kepanitiaan. Beberapa diantaranya 
Yulita Kusuma Sari; Agita Santa Maria; Riris Rinonce Hapsari: Kolaborasi Kreatif Kegiatan Pariwisata dan Pelestarian Budaya di Taman Budaya Yogyakarta (TBY)

menduduki posisi penting seperti ketua dan koordinator acara.

Konsep kreatif ditunjukkan dari berbagai temuan. Sebagai contoh, penggunaan ruang luar untuk ruang pameran dan pertunjukan, menunjukkan sifat organic dan dinamis dari kegiatan tersebut. Tema pameran dan pertunjukan yang merespon isu global didukung dengan menyediakan cinderamata dengan bahan ramah lingkungan. Penggunaan media digital seperti sosial media untuk media publikasi, QR (Quick Response) Code pada display pameran untuk menyampaikan gagasan tema dari barang display kepada penonton, teknologi Virtual Reality pada beberapa display, serta spot-spot yang disediakan untuk menjawab kebutuhan eksistensi pengunjung di dunia virtual.

Setiap pameran menggunakan metode evaluasi yang berbeda. Sebagian menerima umpan balik melalui catatan pengunjung. Sebagian menghitung jumlah pengunjung dari jumlah tiket terjual. Sebagian lagi melakukan evaluasi internal. Tidak semua pameran dan pertunjukan mencatat asal pengunjung, apakah dalam kota, luar kota atau mancanegara.

\section{b. Pasar Tiban}

Acara ini cukup unik berbeda dengan jenis-jenis acara lain di TBY. Pasar Tiban pada umumnya melibatkan lebih banyak komunitas, memadukan beberapa unsur kegiatan tidak hanya jual-beli, namun juga memadukan berbagai seni pertunjukan. Sesungguhnya pasar tiban bukan konsep baru. Konsep ini telah lama ada, bukan Hanya di Indonesia. Pasar Tiban adalah istila untuk pasar yang muncul Hanya pada waktu tertentu, beberapa mengusung tema yang Sangat spesifik seperti yang ada di namun menjadi Pasar tiban saat ini cukup populer apabila melihat trend penyelenggaraan pasar tiban di beberapa tempat akan mengusung berbagai tema seperti makanan organik, flea market (pasar barang bekas), atau tema lain.
Namun di TBY khusus dilaksanakan yang berkaitan dengan budaya sekaligus memperkenalkan ragam barang/kuliner.

Tahun 2019, acara Pasar Kangen Jogja sebagai salah satu pasar tiban rutin di TBY telah memasuki acara ke 12. Acara ini juga merupakan media promosi destinasi Wisata lain di Yogyakarta, seperti desa wisata, atau tour travel agency. Pasar ini menampilkan beragam kuliner dan barang pecah belah tempo dulu yang dipadukan dengan pertunjukan seniman dan musisi lokal. Meskipun pada kerangka acuan kegiatan, maksud dan tujuan Pasar Kangen Jogja bukan sebagai atraksi wisata, namun dapat dikatakan bahwa ada produk wisata yang bisa didapatkan disini.

Antusias pengunjung terlihat dari padatnya kunjungan di pasar ini siang hingga malam hari. Wawancara dengan pengunjung menunjukkan mereka antusia karena: sebagian pengunjung bukan Hanya sekali datang namun pernah datang di tahun-tahun sebelumnya. Mereka bahkan telah mengetahui jadwal penyelenggaraan pasar kangen Jogja sejak bebebrapa bulan sebelumnya. Sebagian pengunjung tersebut mengatakan konsep yang dijual ini unik, pengunjung ingin mengetahui ragam makanan tradisional yang berbeda-beda ditampilkan setiap tahunnya, sebagian ingin merasakan nostalgia pada makanan-makanan tempo dulu, sebagian datang pada waktu tertentu menyesuaikan jadwal pertunjukan seniman atau musisi. Bagi pengunjung yang pertama kali datang, mereka merasa mendapat pengalaman baru. Menurut pengamatan dan wawancara singkat, pengunjung berasal dari dalam kota, luar kota, dan beberapa adalah wisatawan mancanegara yang kebetulan sedang berkunjung ke Yogyakarta.

Lebih lanjut mengenai hubungan nilai-nilai kegiatan dan bentuk kegiatan dapat dilihat pada Tabel 3 . 
Yulita Kusuma Sari; Agita Santa Maria; Riris Rinonce Hapsari: Kolaborasi Kreatif Kegiatan Pariwisata dan Pelestarian Budaya di Taman Budaya Yogyakarta (TBY)

Tabel 3. Nilai-nilai yang terkandung dalam bentuk kegiatan di TBY

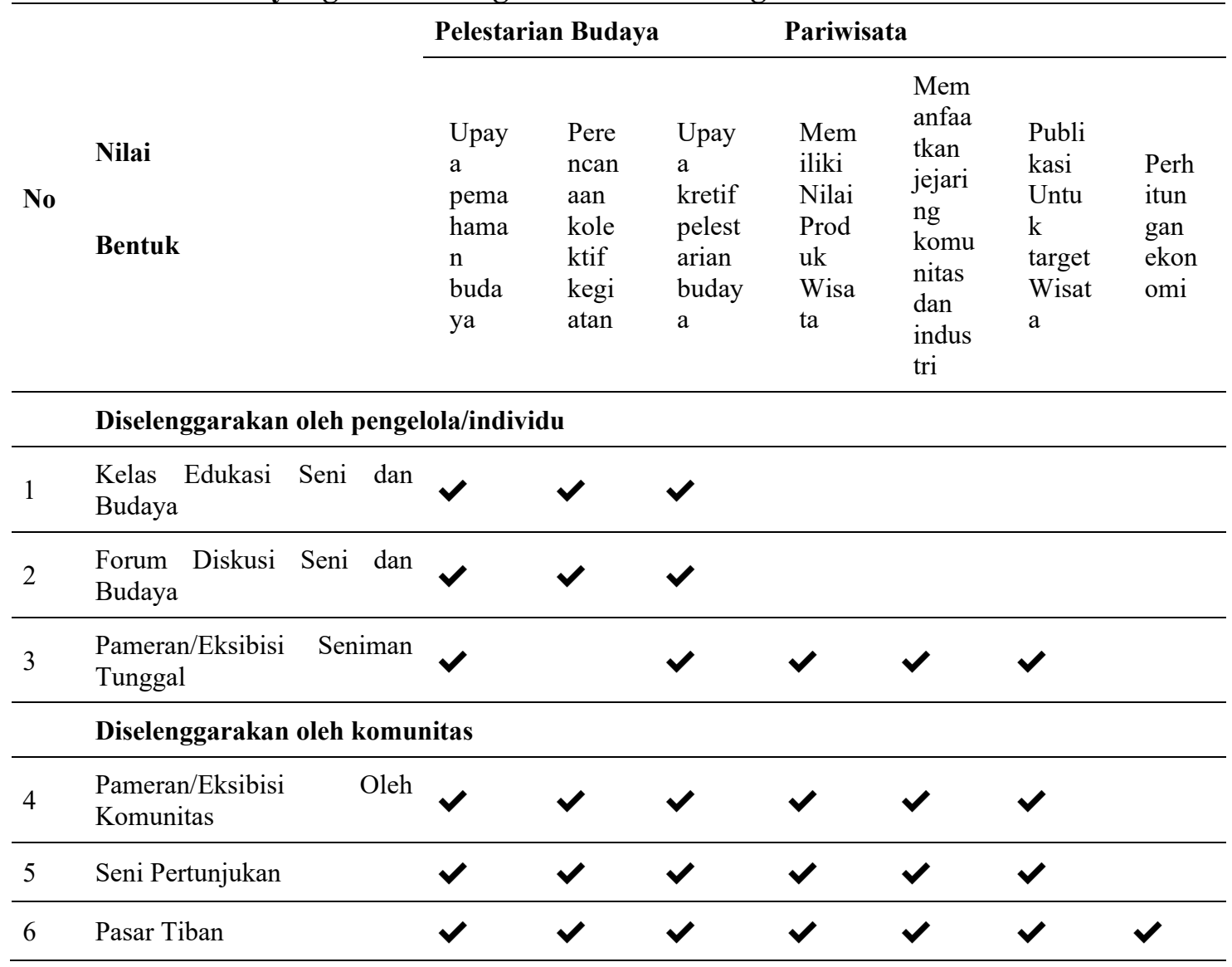

Sumber. Olah data penulis, 2019

Aktor Penggerak

Diagram 3. Aktor Penggerak kegiatan di TBY

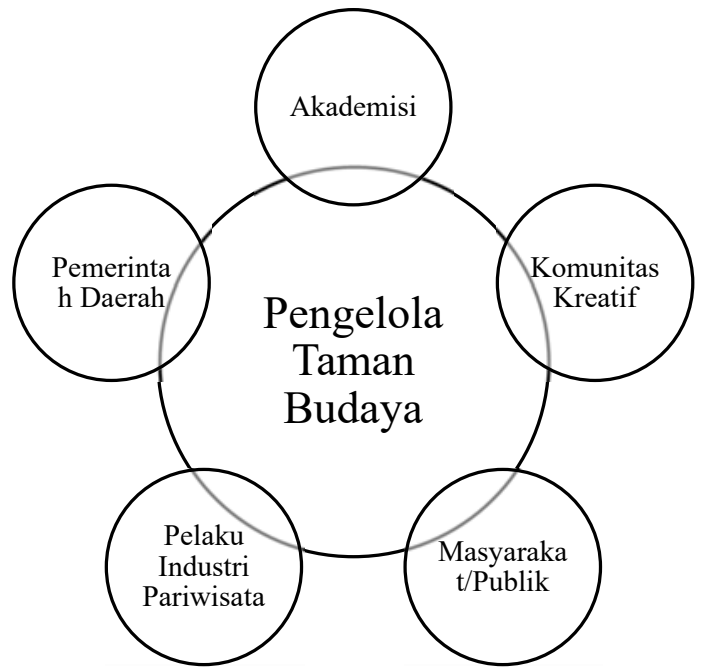

Sumber. Olah data penulis, 2019
Pertama, pemerintah memegang peranan penting dalam kegiatan kreatif di TBY. Pemindahan lokasi TBY dari kompleks Universitas Gadjah Mada ke Gedung Societet mempertimbangkan sisi strategis lokasi untuk mudah diakses oleh publik, dan dekat dengan atraksi wisata perkotaan lain seperti Malioboro, Keraton Yogyakarta, kawasan Titik 0, Pasar Beringharjo, dll. Selanjutnya, sebagai sebuah unit kerja dibawah Dinas Pariwisata Provinsi DIY, TBY mendapatkan dana tahunan dari pemerintah provinsi yang digunakan untuk gaji pengelola, perawatan alat dan gedung, dan operasional kegiatan di TBY. Dana ini digunakan untuk upaya-upaya pengembangan TBY sebagai pusat kebudayaan daerah.

Selain itu dana ini digunakan untuk membiayai berlangsungnya kegiatan yang diselenggarakan oleh pihak TBY. Namun, bukan untuk membiayai kegiatan yang 
diselenggarakan dari pihak di luar TBY. Beberapa acara diselenggarakan menggunakan sumber dana khusus yaitu dana keistimewaan Daerah Istimewa Yogyakarta. Selain sumber dana, keberadaan pengelolaan dibawah pemerintah daerah secara otomatis menjadikan pemerintah sebagai pihak yang berwenang mengambil keputusan tertinggi terhadap segala macam kegiatan dan upaya pengembangan TBY. Pemerintah provinsi dan kota dalam hal ini melalui tenaga ahli memberikan masukan dan menilai kinerja pengelola TBY.

Kedua, aktor penggerak yang berkontribusi besar dalam pelaksanaan kegiatan dan pengembangan TBY yaitu komunitas seni dan budaya. Aktivitas komunitas ini tidak terikat pada tempat tertentu. Yang artinya bahwa pelaksanaan acara mereka dapat saja dilakukan di tempat selain TBY, namun TBY tetap mereka pilih karena selain itu lokasi yang strategis, image pusat pelestarian budaya yang telah melekat. Tidak dapat dipungkiri bahwa acara-acara di TBY juga mengharapkan pengunjung 'tidak terencana', yaitu wisatawan yang sedang berada di atraksi wisata lain di lingkungan sekitar TBY. Komunitas seni budaya inilah yang menjadi tonggak kreativitas di TBY.

Dapat dikatakan bahwa terjadi hubungan simbiosis mutualisme antara komunitas dan pengelola TBY. Dalam hal penyelenggaraan acara di TBY, komunitas tidak berhubungan langsung dengan pemerintah. Komunitas memiliki kekuatan lebih dalam penyelenggaraan kegiatan karena sifat kelompok yang bebas, dan tidak terikat peraturan struktural. Ketidakterikatan tersebut yang memunculkan kreativitas dalam berekspresi dan hal ini disadari oleh pemerintah daerah.

Ketiga, meskipun dikenal sebagai daya tarik wisata budaya, tidak banyak peran pelaku industri pada kegiatan di TBY. Pelaku industri kecil (kuliner, cinderamata, transportasi) berperan sedikit dalam kegiatan dan alur wisata di TBY.

Keempat, Institusi Akademi seperti sekolah dan Universitas berperan sebagai penyelenggara kegiatan seni dan budaya, dan tidak mengusung nilai pariwisata. Bagi lembaga ini, unsur edukasi lebih kuat.

Kelima, yang terakhir yaitu unsur publik, dalam hal ini adalah masyarakat sekaligus pengunjung dan wisatawan.

Unsur ini berperan penting dalam membentuk persepsi masyarakat dan menimbulkan motivasi lebih lanjut terhadap perjalanan wisata dengan untuk lebih mengenal budaya dan terlibat dalam kegiatan pelestarian budaya.

\section{KESIMPULAN}

Keberadaan TBY sebagai atraksi wisata terjadi secara spontan, yang salah satu faktornya dipengarhi oleh motivasi dan persepsi wisatawan terhadap seni dan budaya pada satu ruang interaksi bersama. Meskipun pengelolaan TBY memiliki visi dan misi murni untuk pelestarian budaya, namun potensi budaya sebagai daya tarik Wisata ini ditangkap dengan baik oleh pemerintah, pengelola, maupun komunitas yang terlibat. Setiap pemangku kepentingan menyadari bahwa keberadaan kegiatan di TBY sejalan dengan konsep kota kreatif yang mana ini dianggap sesuai dengan kondisi sosial budaya Yogyakarta.

Kolaborasi antara Pariwisata dan Pelestarian Budaya di Taman Budaya Yogyakarta dapat dilihat dari tiga hal, yaitu (i) Nilai: yaitu nilai yang terkandung dari setiap tujuan kegiatan atau kebijakan di TBY memiliki tujuan baik untuk pelestarian budaya maupun pariwisata (ii) Bentuk, sebagian bentuk kegiatan di TBY dikemas dalam bentuk-bentuk yang mewadahi pelestarian budaya sekaligus pariwisata, (iii) Aktor, yaitu kesadaran dan keterlibatan pemangku kepentingan dalam mewujudkan nilai-nilai budaya sekaligus pariwisata. Tidak semua kegiatan di TBY mengandung nilai kolaborasi kreatif Pariwisata dan Pelestarian Budaya. sebagian Hanya mengandung nilai murni pelestarian budaya. Meskipun begitu, bentuk kegiatan tersebut bertujuan untuk memberi pemahaman, khususnya generasi muda, dengan tujuan akhir mereka dapat 
Yulita Kusuma Sari; Agita Santa Maria; Riris Rinonce Hapsari: Kolaborasi Kreatif Kegiatan Pariwisata dan Pelestarian Budaya di Taman Budaya Yogyakarta (TBY)

berkreasi dan menghasilkan kegiatankegiatan yang mengandung daya tarik.

Salah satu faktor besar yang mendukung tingkat kunjungan yaitu komunitas, khususnya generasi muda sebagai aktor kreatif yang mendominasi penyelenggaraan acara di TBY. Sementara pemerintah berperan mengendalikan kegiatan agar sesuai visi misi namun tetap menjawab potensi TBY sebagai daya tarik wisata perkotaan sesuai semangat kota kreatif, melalui kebijakan dan pengelolaan internal TBY dibawah dinas pemerintahan.

\section{DAFTAR PUSTAKA}

Alwasilah, A. Chaedar. (2006). Pokoknya Kualitatif. Jakarta : Pustaka Jaya

A.S. Dorcheh, B. Mohamed. Local perception of tourism development: A conceptual framework for the sustainable cultural tourism. Journal of Management and Sustainability, 3 (2) (2012), pp. 31-39

MacDonald, C. Understanding participatory action research: A qualitative research methodology option. Canadian Journal of Action Research, 13 (2) (2012), pp. $34-50$

Kakiuchi, Emiko. Culturally creative cities in Japan: Reality and prospects. City, Culture and Society, 7 (2) (2016), pp. 101-108, https://doi.org/10.1016/j.ccs.2015.11.0 $\underline{03}$

Kotler, P. and Keller, K. 2012. Marketing management. Upper Saddle River, N.J.: Prentice Hall.

L.R. Allen, P.T. Long, R.R. Perdue, S. Kieselbach. The impact of tourism development on residents' perceptions of community life. Journal of Travel Research, 27 (1) (1988), pp. 16-21

Macleod, Donald V.L. 2004. Tourism, Globalisation and Cultural Change: an Island Community Perspective. UK: Channel View Publications

Mill, R.C., and Morison, A.M. 1985. The Tourism System. Prentice-Hall International.
Moirano, R, et.al. Creative interdisciplinary collaboration: A systematic literature review. Thinking Skills and Creativity, 35

(2020). https://doi.org/10.1016/j.tsc.2019.1006 $\underline{26}$

Ritzer, George. 2011. Globalization: The Essentials. John Wiley \& Sons Ltd.

Rodrigues, M., and Franco, M. Network and Performance of Creative Cities: A bibliometric analysis. City, Culture and $\begin{array}{lll}\text { Society. } & 20 & \text { (2020), }\end{array}$ https://doi.org/10.1016/j.css.2019.1003 $\underline{26}$

Rosi, Mauro. Branding or sharing? The dialectics of labeling and cooperation in the UNESCO Creative Cities Network. City, Culture and Society. 5 (2014), pp. 107-110

Sangchumnong, Aunkrisa. Development of a sustainable tourist destination based on the creative economy: A case study of Klong Kone Mangrove Community, Thailand. Kasetsart Journal of Social Sciences (2018), https://doi.org/10.1016/j.kjss.2018.02.0 $\underline{02}$

Sari, Y.K., 2012. Dampak Pembangunan Fasilitas Pariwisata terhadap Identitas Kota Yogyakarta. Laporan Penelitian Fakultas Ilmu Budaya UGM. Tidak diterbitkan.

Sklair, Leslie. 2002. Globalization, Capitalism, and Its Alternatives. UK: Oxford University Press

Sofield, Trevor, et.al. Organic 'folkloric' community driven place-making and tourism. Journal of Tourism Management, 61 (2017), pp. 1-22

Ucar, Erdem. Local creative culture and corporate innovation. Journal of Business Research (October) (2018), pp. $60-70$

Vivant, Elsa. Creatives in the city: Urban contradictions of the creative city. Journal of City, Culture and Society, 4 (2) (2013), pp. 57-63 
Yulita Kusuma Sari; Agita Santa Maria; Riris Rinonce Hapsari: Kolaborasi Kreatif Kegiatan Pariwisata dan Pelestarian Budaya di Taman Budaya Yogyakarta (TBY)

Yoeti, Oka. 2008. Perencanaan dan Pengembangan Pariwisata. Pradnya Paramitha. Jakarta, Indonesia.

\section{Laman Referensi}

https://en.unesco.org/creative-

cities/home

https://tby.jogjaprov.go.id/post/art-

for-children.html

https://www.tripadvisor.com/Attracti

on_Review-g294230-d8519866-Reviews-

Cultural_Development_Center_of Yogyakar

ta-Yogyakarta_Region_Java.html

\footnotetext{
i data statistik kepariwisataan DIY tahun 2018, https://visitingjogja.com/19962/statistik-pariwisatadiy-2018/

ii https://www.tripadvisor.com/Attraction_Reviewg294230-d8519866-Reviews-

Cultural_Development_Center_of_Yogyakarta-

Yogyakarta_Region_Java.html

iii https://tby.jogjaprov.go.id/post/profil/detail/visimisi.html diakses pada 24 Agustus 2019

iv pasar tiban (dari Bahasa Jawa), artinya pasar kaget yang muncul pada momen-momen tertentu.
} 